\title{
Macroeconomics of twin-targeting in Turkey: analytics of a financial computable general equilibrium model
}

\section{Cagatay Telli , Ebru Voyvoda \& Erinc Yeldan}

To cite this article: Cagatay Telli , Ebru Voyvoda \& Erinc Yeldan (2008) Macroeconomics of twin-targeting in Turkey: analytics of a financial computable general equilibrium model, International Review of Applied Economics, 22:2, 227-242, DOI: 10.1080/02692170701880767

To link to this article: https://doi.org/10.1080/02692170701880767

巴follished online: 18 Mar 2008.

Submit your article to this journal $\square$

Џ Article views: 76

4 Citing articles: 2 View citing articles ๘ 


\title{
Macroeconomics of twin-targeting in Turkey: analytics of a financial computable general equilibrium model
}

\author{
Cagatay Telli ${ }^{\mathrm{a}}$, Ebru Voyvoda ${ }^{\mathrm{b}}$ and Erinc Yeldan $^{\mathrm{c}}$ \\ ${ }^{a}$ State Planning Organization, Ankara, ${ }^{b}$ Turkey; Middle East Technical University, Ankara; ${ }^{c}$ Bilkent \\ University, Ankara
}

\begin{abstract}
The paper provides an overview of the post-1998 Turkish economy and constructs a macroeconomic computable general equilibrium (CGE) model to illustrate the real and financial sectoral adjustments of the Turkish economy under the conditionalities of the 'twin targets': on primary surplus to gross national product (GNP) ratio and on the inflation rate. We further utilize the model to study three sets of issues: (i) the critical role of the expanded foreign capital inflows in resolving the macroeconomic impasse between the disinflation motives of the central bank and imperatives of debt sustainability and fiscal credibility of the ministry of finance; (ii) reduction of the central bank's interest rates, and (iii) a labor market reform of reducing payroll taxes. Our simulation results suggest that the current monetary strategy, which involves a heavy reliance on foreign capital inflows along with a relatively high real rate of interest, is effective in bringing inflation down; yet it suffers from increased cost of interest burden to the public sector, and strains fiscal credibility. In contrast, given the ex ante constraints of the domestic economy in the short run, an alternative heterodox policy of reduction of the central bank interest rate and lowering of the payroll tax burden in labor markets indicate strong employment and growth effects along with strengthened fiscal credibility.
\end{abstract}

Keywords: twin-targeting; CGE; inflation; central banks

JEL classification: E31, E58

\section{Introduction: Macroeconomics of twin-targeting in Turkey}

After a decade of failed reforms and deteriorated macroeconomic performance, Turkey entered the millennium under a 'Staff Monitoring Program' signed with the International Monetary Fund (IMF) in 1998, and put into effect in December 1999. Following a logic that the successful achievements of the fiscal and monetary targets would enhance the 'credibility' of the economy, the program currently sets the macroeconomic policy agenda in Turkey and relies mainly on two pillars: (1) fiscal austerity that targets a $6.5 \%$ surplus for the public sector in its primary budget ${ }^{1}$ as a ratio to the gross domestic product (GDP); and (2) a contractionary monetary policy (through an independent central bank - CB) that exclusively aims at price stability (via inflation targeting). Thus, in a nutshell the Turkish government is charged to maintain dual targets: a primary surplus target in fiscal balances (at 6.5\% to the GDP); and an inflation-targeting CB whose sole mandate is to maintain price stability and is divorced from all other concerns of macroeconomic aggregates - hence the terms in the title: 'macroeconomics under twin-targeting'.

On the monetary policy front, the Central Bank of Turkey (CBRT) was granted its independence from political authority in October 2001. In what follows, the central bank announced that its sole mandate is to restore and maintain price stability in the domestic markets and that it will

Corresponding author. Email: ctelli@dpt.gov.tr

ISSN 0269-2171 print/ISSN 1465-3486 online 
follow a disguised inflation targeting until conditions are ready for full targeting. Thus, over 2002 and 2003 the CBRT targeted net domestic asset position of the central bank as a prelude to full inflation targeting. Finally on 1 January 2006 the CBRT announced that it will adopt full-fledged inflation targeting.

The purpose of this paper is to provide an assessment of the key macroeconomic developments in Turkey over the post-2001 crisis period and to provide a general equilibrium analysis of the macroeconomic policy alternatives of the twin-targeters. We focus on three sets of issues: first we study the macroeconomics of the expanded foreign capital inflows in resolving (temporarily) the macroeconomic impasse between the disinflation motives of the CBRT and imperatives of debt sustainability and fiscal credibility of the Ministry of Finance. Second, we study the reduction of the central bank's interest rates, and then, as the third step, we implement a labor market reform and study the implications of reducing/eliminating payroll taxes (paid by the employers). To these ends we construct a macroeconomic general equilibrium model with a full-fledged financial sector in tandem with a real sector. Across all policy simulations we exclusively focus on both the fiscal and financial adjustments and study the possible dilemmas of gains in efficiency in the labor markets vs the loss of fiscal revenues to the state.

Our finding is that the current monetary strategy followed by the CBRT that involves a heavy reliance on foreign capital inflows along with a relatively high real rate of interest, is effective in bringing inflation down; yet it suffers from increased cost of interest burden to the public sector and strains fiscal credibility. In contrast, our simulation results suggest that, given the ex ante constraints of the domestic economy in the short run, an alternative heterodox policy of reduction of the central bank interest rate and lowering of the payroll tax burden in labor markets may have strong employment and growth effects. The policy also achieves significant gains in fiscal credibility in the short run. Yet it suffers from increased inflationary pressures in the commodity and the financial markets. Even though observed to prevail at a modest scale in our simulation experiments, the ex ante constraints of maintaining inflationary expectations may lead to intolerance of the CBRT and render the policy ineffective. Thus, maintaining an integrated and coherent policy framework between the monetary and fiscal authorities is seen of prime importance for the success of the policy formulation at the macro scale.

Our premise in this paper is that a proper modeling of the general equilibrium linkages between the production-income generation and production-aggregate demand components across individual sectors as well as responses of the real macro aggregates to financial decisions are essential steps to understand the impact of the current austerity program on the evolution of output, fiscal, financial, and external balances, and on employment. Accordingly, we develop a computable general equilibrium (CGE) model with a relatively aggregated productive sector, a segmented labor market, and a full-blown public sector with a detailed treatment of fiscal balances and financial flows.

The current model shares many of the analytical structures of the Agénor et al. (2006) design in the dynamics of financial transactions, especially with respect to formation of expectations and fragility. It is explicitly designed to capture the relevant linkages between the fiscal policy decisions, financialization constraints and external balances that we believe are essential to analyze the impact of disinflation and fiscal reforms on labor market adjustment and public debt sustainability. We pay particular attention to fiscal issues such as a high degree of debt overhang and fiscal dominance; the link between real and financial sector interactions, and interactions between external (current account) deficits, private saving-investment deficits, and the public (primary balance) surpluses.

We organize the paper under four sections. First, we provide a broad overview of the recent macroeconomic developments in Turkey in Section 2. Here we study, exclusively, the evolution of the key macroeconomic prices such as the exchange rate, the interest rate, and price inflation. 
We also comment on the external balances, the dynamics of external debt, fiscal policy issues and the labor market. In Section 3, we introduce and implement our computable general equilibrium modeling analysis of the alternative policy scenarios to depict the short-run macroeconomic adjustments of the Turkish economy under the conditionalities of the IMF program targets on primary surplus to GDP ratio and on inflation rate. Finally, we provide a brief summary with concluding comments in Section 4.

\section{Macroeconomic developments under IMF staff monitoring}

The growth path of the Turkish economy over the post-1998 period had been erratic and volatile, mostly subject to the flows of hot money. Following the contagion effects of the Asian, Russian and the Brazilian turmoil, the economy first decelerated in 1998 with a growth rate of $3.1 \%$, and then contracted in 1999 at the rate of $-5.0 \%$. The boom of 2000 was followed by the 2001 crisis. The recovery was sharp as the economy has grown at an average rate of 7.1\% over the 2002-2006 period. Price movements were also brought under control through the year and the 12-month average inflation rate in consumer prices has receded from $45 \%$ in 2002 to $7.7 \%$ in 2005 , and from $50.1 \%$ to $5.9 \%$ in producer prices.

The post-2003 period has also meant a period of acceleration of exports, where export revenues reached US\$91.7 billion in 2006. Nevertheless, with the rapid rise of the import bill over the same period, the deficit in the current account reached US $\$ 31.7$ billion (or about $7.9 \%$ of the gross national product (GNP) in 2006). The current account deficit continued to widen in 2007 and reached US\$34 billion over 12 months cumulative period in the first quarter. On the public sector front one witnesses an effort at very strong fiscal discipline. The ratio of central government budget deficit to the GNP was reduced from its peak of $16.2 \%$ in 2001 , to $0.8 \%$ by 2006 . Consequently, the public sector borrowing requirement (PSBR) as a ratio to the GNP fell from 16.1\% to $-3 \%$, indicating a surplus, in 2006 . Table 1 documents the main macro indicators of the post1998 Turkish economy under close IMF supervision.

\subsection{Macroeconomic prices and the monetary policy}

The CBRT initiated an open inflation targeting framework that started on 1 January 2006. The Bank's current mandate is to set a 'point' target of 5\% inflation of the consumer prices. Given internal and external shocks, the Bank has recognized an internal (of 1\%) and an external (of 2\%) 'uncertainty' band around the point target. The Bank has announced that it will continue to use the overnight interest rates as its main policy tool to reach its target. It is stated explicitly that the 'sole objective of the CBRT is to provide price stability', and that all other possible objectives are out of its policy realm. ${ }^{2}$

Despite the positive achievements on the disinflation front, rates of interest remained slow to adjust. The real rate of interest remained above $10 \%$ much of the post-2001 crisis era, and generated heavy pressures against the fiscal authority in meeting its debt obligations (Table 1). The persistence of the real interest rates, however, had also been conducive in attracting heavy flows of short term speculative finance capital over 2003 and 2006. This pattern continued into 2007 at an even stronger rate.

Inertia of the real rate of interest is enigmatic from the successful macro economic performance achieved thus far on the fiscal front. The credit interest rate, in particular, had been constrained by a lower bound of $16 \%$ despite the deceleration of price inflation. Consequent to the fall in the rate of inflation, the inertia of credit interest rates translates into increasing real costs of credit.

High rates of interest were conducive in generating a high inflow of hot money finance to the Turkish financial markets. The most direct effect of the surge in foreign finance capital over this 


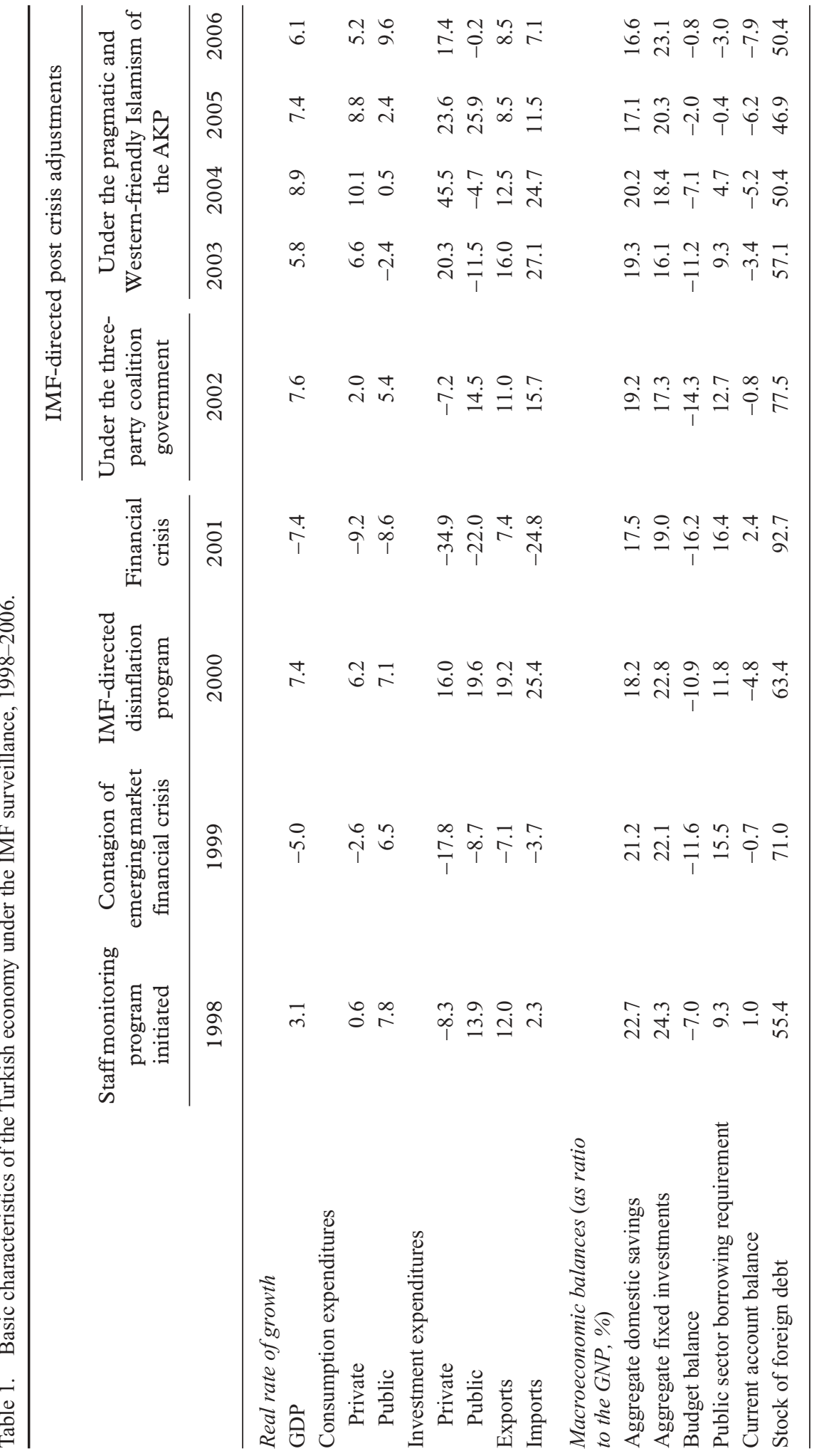




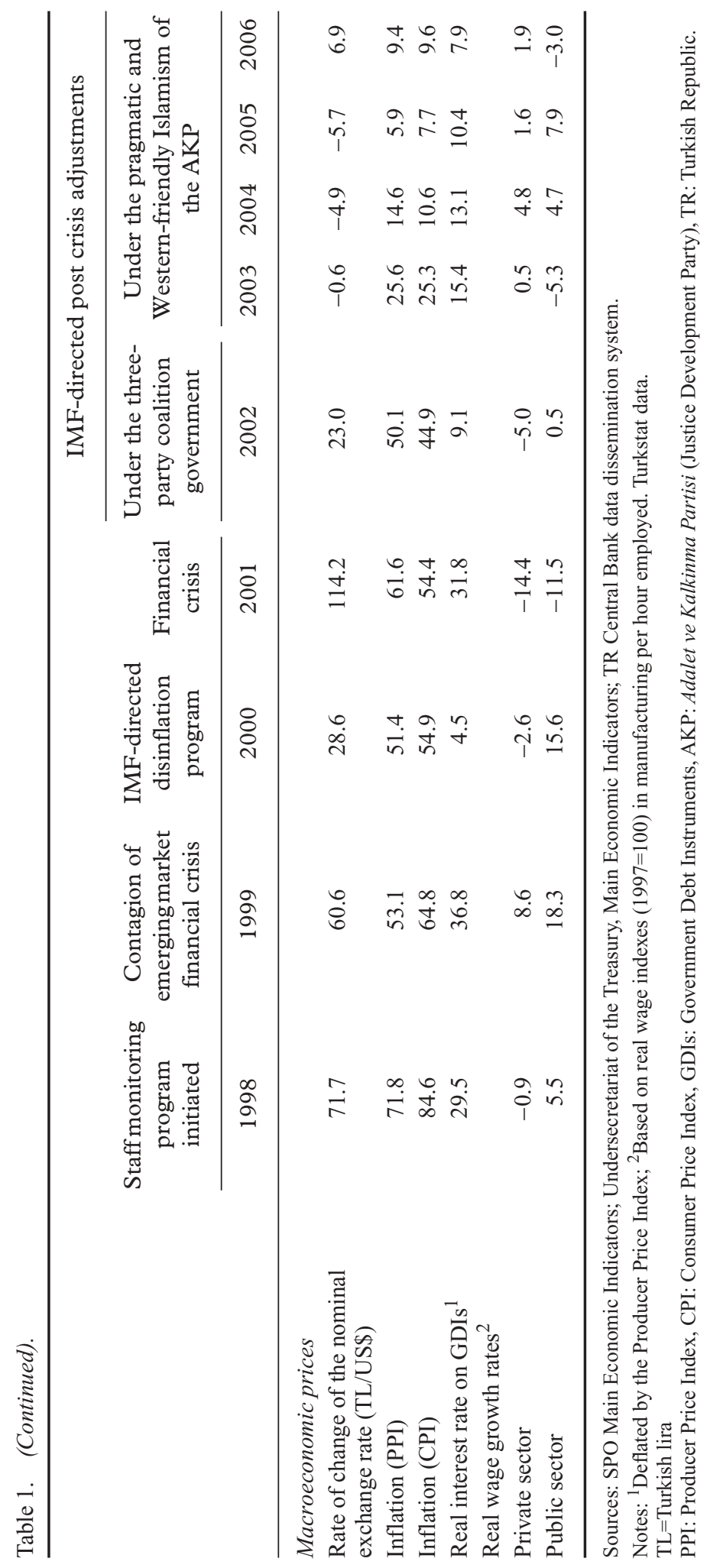


period was felt in the foreign exchange market. The over-abundance of foreign exchange supplied by the foreign financial arbiters seeking positive yields led significant pressures for the Turkish lira to appreciate. The lira appreciated by as much as $40 \%$ in real terms against the US dollar and by $25 \%$ against euro (in producer price parity conditions, over 2002-2006).

\subsection{Fiscal policy and debt management}

The current fiscal policy stance in Turkey relies primarily on expenditure restraint. Data reveal a secular fall in the budget deficit through the post-2001 crisis adjustments and is now reduced to less than $1 \%$ to the GNP. As discussed above, much of the aggregate budget expenditures can be explained by the high costs of debt servicing, and the main logic of the current austerity program rested on maintaining the debt turnover via only primary surpluses. All fiscal policies are directed to securing debt servicing at the cost of extraordinary cuts in public consumption and investments. Within total expenditures, the share of public investment has fallen from $12.9 \%$ in 1990 to $5.1 \%$ in 2003 . As a ratio to the GNP, public investment stands at less than $2 \%$ currently.

All of these painful adjustments on the fiscal front can be contrasted against the 'gains' over the existing debt burden of the public sector. Data from the Ministry of Finance ${ }^{3}$ reveal that, as a ratio to the GNP, gross public debt has fallen from $68.1 \%$ in 2000 to $63.1 \%$ by the end of 2006 , a decline of only 5 percentage points. This could have been achieved despite the very rapid raise in the rate of growth of GNP (7.2\% per annum over the whole period), and the very strict fiscal austerity measures of primary surplus targets (of $6.5 \%$ to the GNP for 2002 and beyond). Furthermore much of this decline came only after 2005, and all of it is due to the decline in the ratio of foreign debt to the GNP. As a ratio to the GNP, public external debt has declined from $25.2 \%$ in 2000 to $16.9 \%$ in 2006 ; while the domestic debt burden has increased from $43.1 \%$ to $46.2 \%$ over the same period.

\subsection{Persistent unemployment and jobless growth}

Yet the most striking observation on the Turkish labor markets over the post-2001 crisis era is the sluggishly slow performance of employment generation capacity of the economy. Despite the very rapid growth performance across industry and services, employment growth has been meager. The rate of open unemployment was $6.5 \%$ in 2000 ; increased to $10.3 \%$ in 2002, and remained at that plateau despite the rapid surges in GNP and exports. Open unemployment is a severe problem, in particular, among the young urban labor force reaching $26 \%$. If we add the TURKSTAT data on the underemployed people, the excess labor supply (unemployed + underemployed) is observed to reach $16.9 \%$ of the labor force by the end of 2006 (see Figure 1).

Thus to conclude, two important characteristics of the post-crisis adjustment path stand out: first is that the post-2001 expansion is observed to be concomitant with a deteriorating external disequilibrium and intensifying fragility. Second, the output growth contrasts with persistent unemployment, warranting the term 'jobless growth'.

The foregoing facts bring the following tasks to our agenda: (1) What are the viable policy choices in combating unemployment in the short run, and under the conditionalities of the "twin targets'? (2) Given our assessments of fragility conditions currently prevailing in Turkey, what are the short run effects of a reduction in the interest cost of the central bank credit in terms of output, employment, foreign indebtedness and other macro aggregates?

We now turn to the analytics of general equilibrium with the aid of our CGE model to study these questions. 


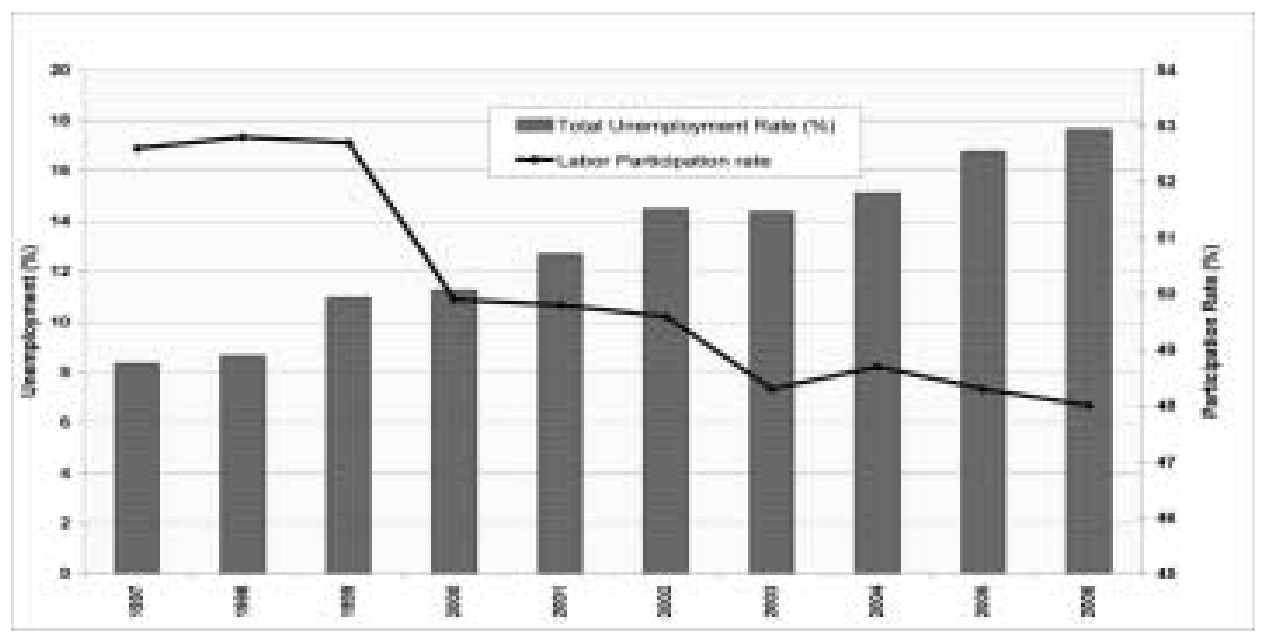

Figure 1. Labor participation rate and total unemployment.

Source: Turkish Statistical Institute (TURKSTAT), Household Labor Force Surveys.

\section{Computable general equilibrium modeling analysis}

\subsection{The algebraic structure of the model and adjustment mechanisms ${ }^{4}$}

\section{Product markets}

The model is fairly aggregate over its microeconomic structure but accommodates a relatively detailed treatment of the public accounts, and of real-financial sector linkages. There are four production sectors: agriculture, industry, private services and public services. There is a financial sector with a full-fledged banking segment, a central bank, enterprises, government and household portfolio instruments.

Sectoral production is modeled via multi-level functions. At the top level total output is given as a Leontieff specification of value added and intermediate inputs. The value-added in each sector is generated by combining labor, as well as public and private physical capital. At the last stage of this multi-level production a sector specific public capital combines with the composite input under a Cobb-Douglas specification. The composite primary input in turn, is defined to be a combination of private capital and labor aggregate $L_{i}$ through a constant elasticity of substitution (CES) type of production function.

Public capital is assumed to be fixed and sector specific. Private capital is mobile across sectors and the movement is directed by the difference in the differentiated private profit rates. Labor's wage rate is fixed in the short run and the labor market clears through quantity adjustments on employment.

Households save a fraction $0<s^{P}<1$ of their disposable income. The saving rate is considered to be a positive function of the expected real interest rate in domestic currency denominated deposits:

$$
s^{P}=s_{0}^{P}\left(\frac{1+\operatorname{int} D}{1+E[\operatorname{Inf}]}\right)^{\sigma_{\mathrm{SAV}}^{H}} \quad s_{0}^{P}>0
$$

with $E[\operatorname{Inf}]$, the expected inflation rate and $s_{\mathbf{0}}^{P}$, is a scaling parameter. 
Private capital investment is assumed to depend on a number of factors: The first is the growth rate of real GDP, which captures the regular accelerator effect. This effect is positive. The next one is the negative effect of the expected real cost of borrowing from the domestic banks. Specifically, private investment demand is represented by:

$$
\frac{P K \cdot P^{\mathrm{INV}}}{N o m G D P_{-1}}=\left(1+\frac{\Delta \text { RealGDP }}{\text { RealGDP }_{-2}}\right)^{\sigma_{\mathrm{ACC}}}\left(\frac{1+\mathrm{int} L D}{1+E[I N F]}\right)^{-\sigma_{\mathrm{INTL}}}
$$

where Nom GDP and RealGDP are the nominal and real values of the GDP, respectively, valued at market prices.

\section{Financial markets, asset allocation and risk premia}

A household's financial wealth is typically allocated to five different categories of assets: domestic money $H^{D}$, domestic-currency denominated bank deposits held at home $D D^{H}$, foreigncurrency denominated deposits held domestically ${ }^{5}$ FDDom $^{H}$, holdings of government bonds $G D I^{H}$, and portfolio investments abroad ${ }^{6} P F I^{H}$.

The household demand function for currency is positively related to consumption and negatively related to expected inflation and interest on domestic-currency denominated deposits, int $D$. It also depends negatively on the interest on foreign currency denominated deposits, intDF, adjusted for the expected rate of depreciation. Household allocation on domestic vs foreigncurrency deposits is a function of the interest rate on domestic-currency denominated deposits as a ratio to the rate of return on foreign-currency denominated deposits held at home. Total portfolio investments of households abroad is taken to be a fixed fraction of total household financial wealth, and the demand for government bonds by households is regarded as a function of the expected bond interest rate $E[$ int $B]$.

In an environment where government debt instruments offer a high real rate of return, a crucial decision of the enterprise sector is how to allocate their profits between funds to investment vs bonds. This decision depends on the average profit rate expected from production activities, and expected returns on government debt instruments:

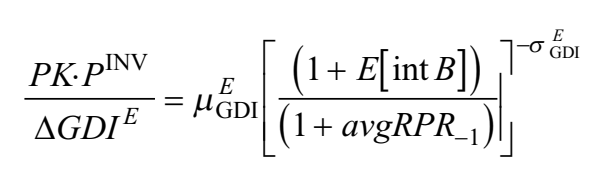

Banks set both deposit and lending interest rates. The deposit rate on domestic currency denominated deposits intD, is set equal to the borrowing rate from the central bank int $R$. The deposit rate on foreign-currency deposits at home, however, is set on the basis of the (premium inclusive) marginal cost of borrowing on world capital markets:

$$
(1+\operatorname{intDF})=(1+\operatorname{intFW})
$$

Following Agénor et al. (2006), the risk-premium inclusive foreign interest rate is formulated as a function of the (risk-free) world interest rate $i n t F W^{\mathrm{RF}}$, and an external risk premium:

$$
(1+\operatorname{int} F W)=\left(1+i n t F W^{\mathrm{RF}}\right)(1+r i s k p r)
$$

in which the risk premium is assumed to be a function of total foreign debt to exports ratio: 


$$
\text { riskpr }=\text { contag }+\frac{\kappa}{2}\left(\frac{\sum \text { ForDebt }}{\sum E_{i}}\right)^{2}
$$

In equation (6), contag is an exogenous coefficient used to capture the characteristic changes in the 'sentiments' in world capital markets. The bank lending rate, int $L D$, then is defined as a weighted average of the cost of borrowing from the $\mathrm{CB}$ and the cost of borrowing from foreign capital markets taking into account the (implicit) cost of holding required reserves.

\section{Public sector, credibility and expectations}

Because the government debt instruments constitute a relatively significant share of the assets in the domestic financial markets in Turkey, modeling the interactions between the public sector and the CB (the so called 'fiscal dominance') is one of the crucial concerns of this study. With a mandated target of the 'primary surplus-GNP ratio', the government's fiscal policy is basically centered around the primary balance. A fiscal deficit is still realized if interest costs on the outstanding public debt exceeds the primary surplus. The public sector borrowing requirement, PSBR, is financed by either an increase in foreign loans or by issuing bonds. Of crucial importance is the realization of the interest rate on government bonds. The expected rate of return on this instrument is modeled as:

$$
E(\operatorname{intB})=\left(1-P R^{\text {default }}\right) \operatorname{int} B
$$

where $P R^{\text {default }}$ denotes the 'subjective' probability of default on the current stock of public debt as perceived by the 'markets'. This variable is set to depend on, among various alternative measures, the current debt stock to tax revenues ratio with a one-period lag:

$$
P R^{\text {default }}=1-\exp _{\{}\left\{-\gamma_{0}\left[\left.\frac{\left(\text { DomDebt }_{-1}{ }^{G}+\text { ForDebt }_{-1}{ }^{G}\right)}{\text { GTaxRev }_{-1}}\right|_{\mid}\right]\right\}
$$

The probability of default, $\mathrm{PR}^{\text {default }}$, has also a further effect on inflation expectations in such a way that the less the probability of default that is perceived, the higher the chances for the 'declared' inflation target to materialize. Following Agénor et al. (2006) the expected inflation rate is formulated as a function of the government's 'credibility indicator', $\left(1-\mathrm{PR}^{\text {default }}\right)$, and the targeted rate of inflation in the previous period:

$$
E(\text { inf })=\left(1-P R^{\text {default }}\right) \text { inf }^{\text {trgt }}+P R^{\text {default }} \text { inf } f_{-1}
$$

Note that, under such a setting, the expected rate of return will reflect the probability and will demand compensation in the form of higher nominal interest rates on government bonds. For a given probability of default, a continued increase in the supply of bonds will require an increase in interest rates to evoke investors' demand. Also, an increase in the stock of debt will lead to a rise in the probability of default, which will also raise the prevailing interest rate on government bonds.

\subsection{General equilibrium analysis of alternative policy environments}

Now we utilize our CGE apparatus to provide a general equilibrium analysis of the macroeconomic policy alternatives under twin-targeting. In what follows, we will focus on three sets of 
issues to depict three alternative policy environments: first we highlight the important role of the expanded foreign capital inflows in resolving (temporarily) the macroeconomic impasse between the disinflation motives of the CBRT and imperatives of debt sustainability and fiscal credibility of the ministry of finance. Second, we implement a 'fiscally benign' monetary policy of reducing the interest rate charged by the CBRT. Third, we complement the interest rate reduction policy with a labor market reform and study the implications of reducing/eliminating payroll taxes (paid by the employers). Our simulation experiments are implemented as one-shot, comparative-static exercises. The results are are listed in Table 2.

\section{EXP-1: Macroeconomics of foreign capital inflows}

The post-2001 Turkish economy has benefited quite extensively from the recent surge of financial flows. The increased buoyancy in the global financial markets led both to a fall in the rates of interest in the global markets and also served for provision of expanded liquidity, propelling consumption and investment expenditures. Mostly driven by the private portfolio flows, the net annual inflow of finance capital into the 'new emerging market economies' totaled US\$456 billion in 2005, before receding to US\$406 billion in $2006 .^{7}$ These magnitudes exceeded the previous peaks hit in the global financial markets before the eruption of the 1997 Asian crisis.

As outlined in Section 2 above, Turkey too, had been one of the major beneficiaries of this financial glut. Balance of payments data indicate that finance account has depicted a net surplus of US\$103.3 billion over 2003-2006. About half of this sum (US\$151.2 billion) was due to credit financing of the banking sector and the non-bank enterprises, while a third (US\$32.8 billion) originated from non-residents' portfolio investments in Turkey. It is also observed that $64 \%$ of the total inflows (net financial flows plus errors and omissions) was used for financing the current account deficit which had totaled US $\$ 71.8$ billion over the same period; while $36 \%$ had been used for reserve accumulation of the CBRT.

In this first policy experiment we start by studying the macroeconomic adjustment mechanisms against this continued inflow of finance capital into the Turkish economy. To this end, we exogenously increase the total inflow of portfolio investments from abroad, $P F I^{R O W}$, by a factor of US $\$ 30$ billion (roughly the realized net cumulative flow over 2003-2006). No change in the CBRT's current monetary policy stance is envisaged with respect to the level of interest rates and/ or exchange rate administration. ${ }^{8}$ The exchange rate was left to full float with the rate determined by the free play of foreign exchange market transactors. Our results are appear under the column EXP-1 in Table 2.

The immediate effects of the increased inflow of foreign capital are felt in the currency markets. The exchange rate appreciates by $9.5 \%$ and cost savings on the import side lead to a fall in the inflation rate to $18.7 \%$, from $25.3 \%$. Appreciation of the exchange rate leads to rise in imports and the current account deficit widens to reach $8.7 \%$ as a ratio to the GDP, from its base value of $3.7 \%$. The domestic counterpart of the widening current account deficits is the expansion of private investment (by 2.4 percentage points as a ratio to GDP) and of private consumption (by 2.1 percentage points as a ratio to GDP). The monetary base expands by $20 \%$ and serves for the liquidity requirements of this expansion.

The aforementioned expansion of economy is limited, however, only to the private sector. Given the fiscal constraint on the primary surplus target, the government's room for maneuver is limited on the expenditure side. This constraint becomes even more binding as the domestic economy continues to operate with a significantly high real interest burden. It has to be remembered that a critical feature of the simulated policy environment is that the $\mathrm{CB}$ continues to maintain its interest rate at the already high level. As the economy disinflates, however, the real cost of credit increases even further. The interest cost on government's debt instruments, in particular, expands 


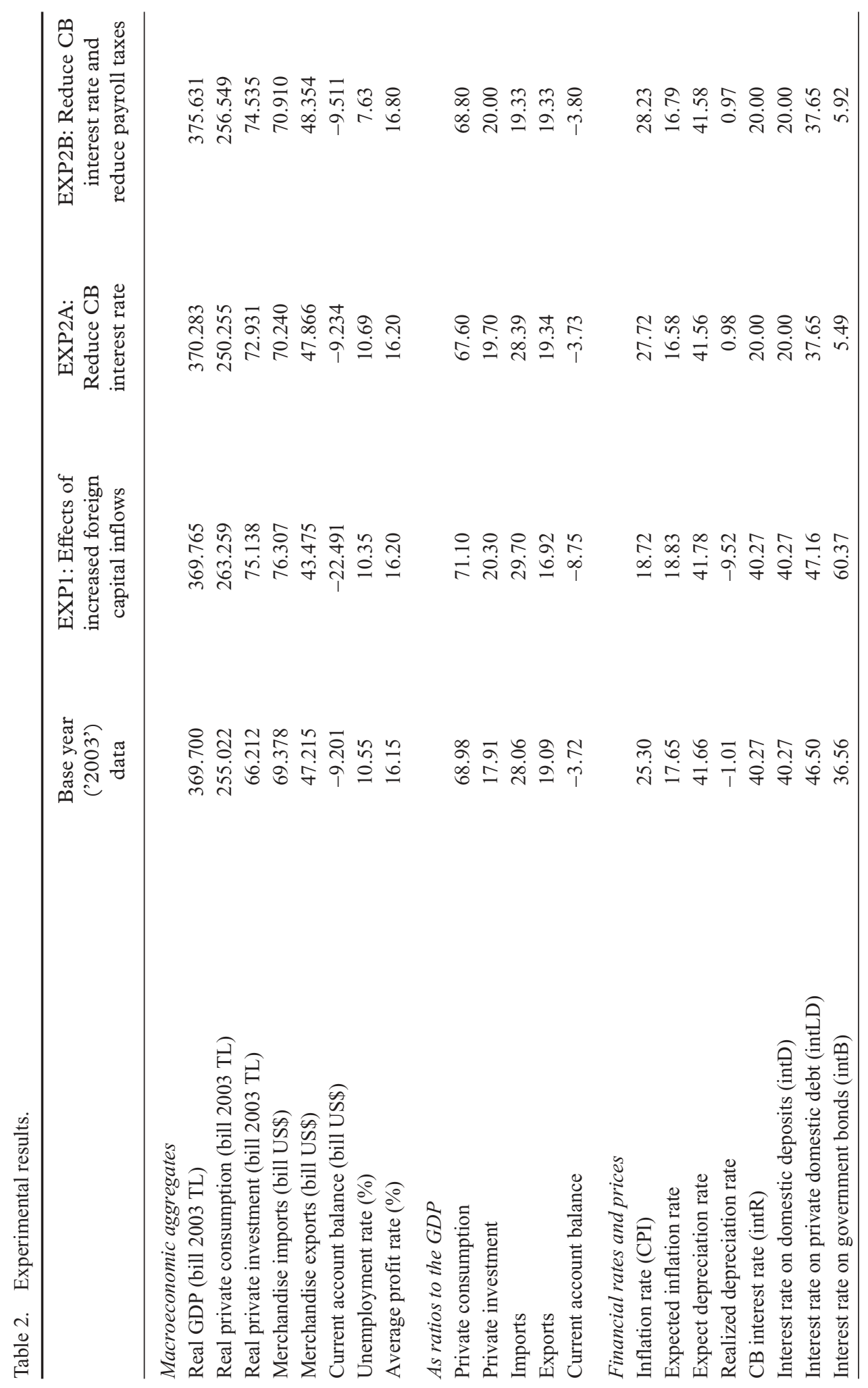




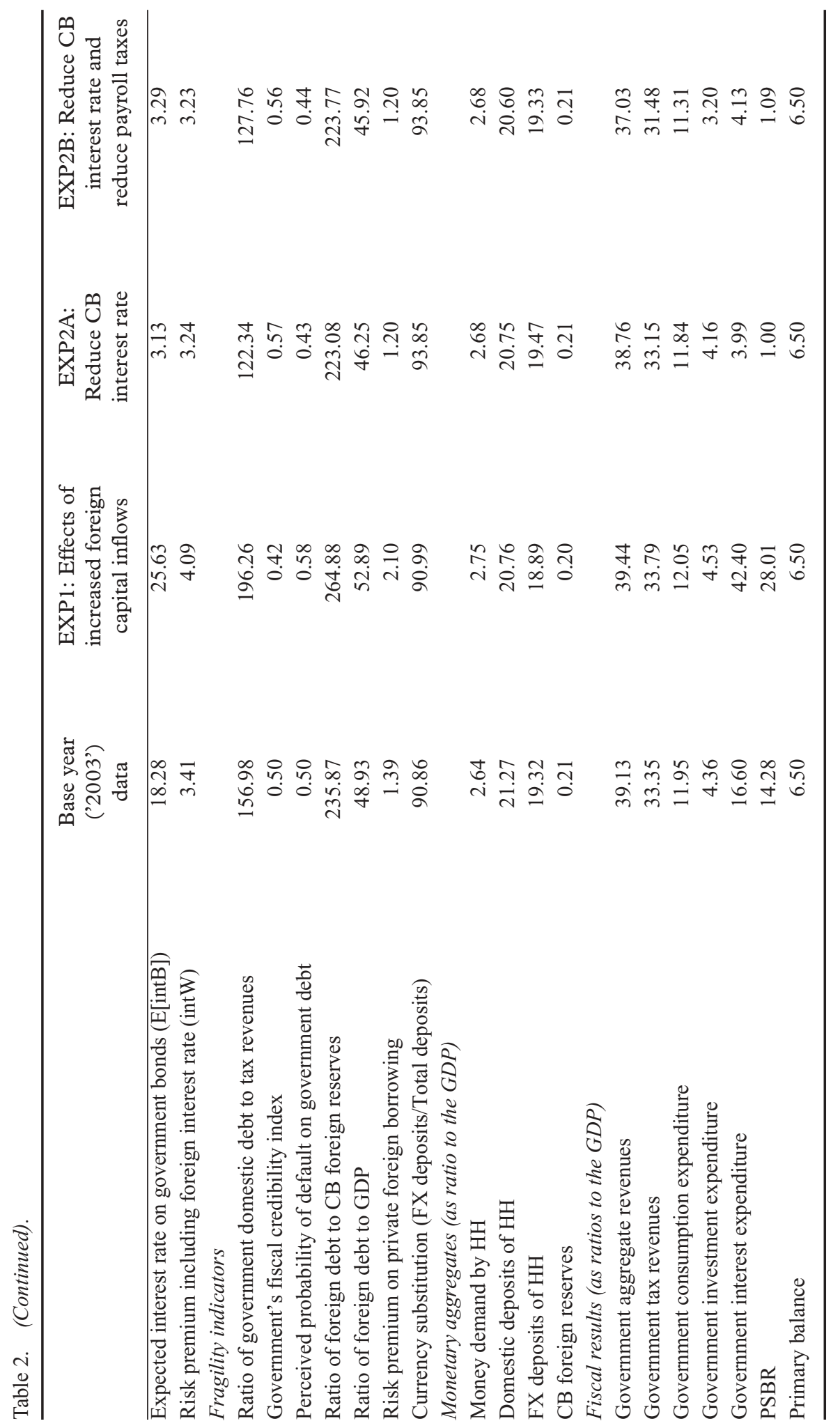


to $60 \%$ from $36.3 \%$. Government's interest expenditures as a ratio to the GDP rises to $25 \%$ and that of the public sector borrowing requirement (PSBR) increases to $28 \%$. Consequently the credibility index falls to 0.43 from its value of 0.50 , and leads to a rise in the subjective probability of default.

This impasse is further accentuated with the rise of foreign indebtedness and consequent external fragility. We observe that the stock of external debt increases both as a ratio to the GDP (from $48.9 \%$ to $52.9 \%$ ) and to the foreign reserves of the CB (from $235 \%$ to $264 \%$ ). As a result, the risk premium on the Turkish liabilities in the world markets increases by 6 percentage points.

\section{EXP-2A: Reduce the CB interest rate}

Given the rather high costs of disinflation in terms of high fiscal and external fragility in the previous experiment, the natural policy question is to study the effects of a reduction in the interest rate charged by the $\mathrm{CB}$. The cost of $\mathrm{CB}$ liquidity is held responsible by many scholars for the external debt cycle. There is a general call for reduction of the CB's rate of interest to escape the trap of speculative inflows of finance leading to appreciation and more inflows, with the consequent widening of the current account deficit and the rise of external indebtedness. Thus, in this experiment we reduce the $\mathrm{CB}$ interest rate by half.

Note that given the algebraic characterization of the loanable funds market, the CB interest rate has a direct effect on the determination of the deposit interest rate of the domestic banks. Thus, intD is reduced by the same magnitude (50\%) immediately. With declining rates of interest on deposits the banks find it possible to lower their credit interest rate charged to the enterprises (int $L D$ falls by 8 percentage points). Private investment expenditures increase by 1.9 percentage points as a ratio to the GDP.

The distinguishing adjustment mechanism at work is the expenditure switching of private consumption with investment. As private consumption expenditures are reduced by 2 percentage points as a ratio to the GDP, domestic savings could be generated to sustain the expansion in investments; thus, the net effect on the external balances remains modest. Thus, the current account balance is affected only marginally and the (nominal) adjustments in the exchange rate are revealed to be modest as well, with a realized depreciation of less than $1 \%$.

What brings forth this adjustment in the private expenditure patterns is the inflation tax. Price inflation accelerates by 2.7 percentage points, and causes a downward shift of aggregate private consumption. The acceleration of inflation further strengthens the decline of the real interest costs. This leads to an improvement in the fiscal balances, where the PSBR is observed to decline to less than $1 \%$ of the GDP, and the credibility index increases by 7 percentage points.

It is not clear, however, whether the $\mathrm{CB}$ would be willing to tolerate the resultant increase of the inflation rate, which turns out to be the crucial adjusting variable in this environment. A further issue is that even though the fiscal results of the policy are observed to be benign, the employment gains remain quite meager. Unemployment rate persists at above the $10.5 \%$ level, and it is to this problem we aim to tackle in the next experiment.

\section{EXP-2B: Complement $C B$ interest rate reduction with labor tax reform}

In this experiment we complement the CB's interest reduction strategy with a labor tax reform. Keeping the CB's interest rate at its reduced level (at half of the base run value), we now implement a further reduction on taxes paid by employers of labor.

Turkey has one of the highest tax burden on the labor markets. Employer-paid social security contributions averaged about 36\% of total labor costs during 1996-2000; it has been argued that these high social security taxes create strong disincentives to job creation. More generally, many 
observers have called for a thorough overhaul of Turkey's social insurance system. Ercan and Tansel (2006) too, state that both the red tape and non-wage labor costs are higher in Turkey relative to, for instance, OECD averages. Likewise, Tunal1 (2003) indicates that employee contribution to social security system can be as high as $15 \%$ while employer in typical risk occupation contributes as much as $22.5 \%$.

The results of the experiment are depicted under column EXP-2B in Table 2. Clearly, the most important observation is the effects on unemployment rate and on fiscal balances. Unemployment rate falls by around 3 percentage points, and the real GDP expands by $1.7 \%$ upon impact. We find, however, that the main adjustment falls on public investments and then on the price inflation. The first outcome is the direct result of the fiscal administration under the current austerity program. Once the primary surplus constraint is met, the rest of the public expenditures are calculated. Thus, within the context of our experiment, as tax revenues are curtailed, the government finds it necessary to adjust public investments downwards. As ratio of GDP, public investments are observed to fall to $3.2 \%$ from its base value of $4.4 \%$ (a significantly low rate itself).

The effect on fiscal accounts is also emphasized by the fall in the ratio of government tax revenues against public debt stock. The aggregate tax revenues fall by almost 2 percentage points; yet, given the cost savings on the interest expenditures, the overall solvency of the public sector remain improved. Thus, the lower interest rate policy is enacted here as an important component of the labor tax reform policy. With a reduced interest burden over the public sector, the CBRT facilitates the fiscal authority to alleviate pressures on the fiscal balances that would have emerged as a result of reduced labor tax revenues. With accelerated growth in GDP and lower interest costs, the fiscal balances improve, with consequent gains in fiscal credibility. ${ }^{9}$

At the outset, the trade-offs as suggested by the simulation exercise under EXP-2B seem modest and not severely binding: at a loss of 2.9 percentage point increase of the inflation rate (from $25.3 \%$ to $28.2 \%$ ), the gains in fiscal credibility and employment are found to be relatively robust. Given that under the macroeconomic adjustments of the experiment the external balances were not strained any further, equilibrium in the foreign exchange market seems to be maintained, as well.

\section{Concluding comments and policy discussion}

The analysis of this paper reveal that the current monetary strategy followed by the CBRT that involves heavy reliance on foreign capital inflows along with a relatively high real rate of interest, is effective in bringing inflation down, yet it suffers from increased cost of interest burden to the public sector and strains fiscal credibility. It also leads to excessive foreign indebtedness with increased external fragility. Against this background, we utilized the CGE model to search for applicable alternative policy regimes starting from the immediate short-run. Our results indicate that a heterodox policy of (i) reducing the CB's interest rates; along with (ii) lowering the (payroll) tax burden in the labor markets offers a viable environment in the short run, with accelerated growth and improved employment outcomes. The first arm of the policy, namely, reduction of the CBRT interest rate, is important to facilitate the improvement in fiscal balance (and fiscal credibility) at a time when tax monies from labor taxes are expected to be reduced. Further, with lower payroll taxes levied on employment in production, the employers are led to increase employment demand (and also be more willing, most probably, to employ 'formal' labor, and reduce the unrecorded activities along with informalization of the labor markets; issues that our model is not well-equipped to address).

With increased credibility of the public sector and lower rates of unemployment, the returns to the heterodox policy reform agenda are quite benign. However, all these come at visible 
opportunity costs; in particular on the inflation side. As lower interest rates boost domestic investment expenditures and the domestic economic activity is revived as a result of expanded employment, inflationary pressures accumulate in the commodity and financial markets. It is not so clear at the outset, how tolerant the CBRT would be to the acceleration in inflation. Even though our results are quite modest on the pace of both realized and expected rates of inflation, it is clearly an important constraint that merits close observation in the Turkish macroeconomic environment. It is, in fact, mainly for this reason that we maintain some of the key features of the current austerity program in the short run with respect to expectations management. Of particular importance among these is the signaling effect of the primary surplus target. One alternative policy environment that we simulated sets the fiscal balances with the programmed target of $6.5 \%$ primary surplus ratio to the GNP, rather than proposing a drastic break away from it. In fact, with a proper emphasis on dynamics, a direct case can clearly be proposed to stimulate domestic investment expenditures with a policy of lower interest rates, and advocating a fiscal policy of high public investments toward enhancing human capital formation and social infrastructure. Rather than cutting public investments on health, education and social infrastructure, a case can be forwarded to disregard the rising PSBR to GDP ratio in the short run, and implement a fiscal policy to maintain a level of household income capable of addressing to the tasks of accumulating human capital. Yet, given the short run framework of our current modeling framework, we choose to abstain from making ad hoc statements regarding the dynamic consequences of such a policy environment, an issue that had been dealt elsewhere more effectively (see, e.g. Gibson 2005; Voyvoda and Yeldan 2005; Independent Social Scientists' Alliance 2006).

Above all, our simulation experiments clearly underscore the importance of maintaining an integrated and coherent policy framework between the monetary and fiscal authorities. Given the acuteness of the perceived dilemmas on disinflation and fiscal credibility, the resolution of the current impasse will surely necessitate a more tolerant view over the programmed targets (on both inflation and the primary surplus ratio) as well as a coherent and a mutually supportive macro policy design. Furthermore, there is a clear case for the acute need to design viable policies to diminish the exposure of the domestic economy (in particular of the financial markets) to short term, speculative foreign capital. This, in turn, may necessitate implementation of capital management techniques to gear inflows towards longer maturities.

\section{Acknowledgement}

We are indebted to Korkut Boratav, Yilmaz Akyüz, Jerry Epstein, Bill Gibson, Geoffrey Woglom and to the members of the Independent Social Scientists' Alliance for their valuable comments and suggestions on previous versions of the paper. Previous versions of the paper were presented at the Istanbul Conference of the EcoMod in June 2005; the 9th Congress of the Turkish Social Sciences Association (December 2005, Ankara); the Ankara Congress of the Turkish Economics Association (September 2006); and seminars at Bilkent, METU, Bogazici, Utah, Massachusetts - Amherst, Connecticut, and the Central Bank of Turkey. Research for this paper was completed when Yeldan was a visiting Fulbright scholar at the University of Massachusetts - Amherst for which he acknowledges the generous support of the J. William Fulbright Foreign Scholarship Board and the hospitality of the Political Economy Research Institute at the University of Massachusetts - Amherst. Needless to mention, the views expressed in the paper are solely those of the authors' and do not implicate in any way the institutions mentioned above.

\section{Notes}

1. That is, balance on non-interest expenditures and aggregate public revenues. The primary surplus target of the central administration budget was set $5 \%$ to the GNP. 
2. Further institutional details of the CB's inflation targeting framework can be found at the December 2005 document, 'General Framework of Inflation Targeting Regime and Monetary and Exchange Rate Policy for 2006', available on line at http://www.tcmb.gov.tr/yeni/announce/2005/ANO2005-45.pdf

3. www.maliye.gov.tr

4. http://www.peri.umass.edu/Alternatives-to.382.0.html

5. By allowing households to hold foreign-currency denominated deposits in the domestic banking system, we try to represent the high level of dollarized liabilities in the Turkish financial system (see Table 1)

6. Both residents' portfolio investments abroad, $P F I^{H}$ and non-residents' portfolio investments at home, $P F I^{\mathrm{ROW}}$ are incorporated in the model in order to capture any real-economy effects of these 'speculative' means, which we believe are important in understanding the growth pattern of the Turkish economy in the last decade.

7. See, e.g. Institute for International Economics, http://www.iie.com.

8. It has to be noted as a reminder, that the current rate of interest set by the CBRT is already significantly high in real terms. Maintaining high real rates of interest was, but one of the discretionary measures of the CBRT in an attempt to reduce inflation by curtailing domestic demand expansion, as well as to sustain the inflow of foreign capital to cover the widening current account deficit.

9. Note, however, that this comparison is valid against the base run. One witnesses a slight loss in fiscal credibility relative to $E X P-2$.

\section{References}

Agénor, P.R., H.T. Jensen, M. Verghis, and E. Yeldan. 2006. Disinflation, fiscal sustainability, and labor market adjustment in Turkey. In Adjustment Policies, Poverty and Unemployment: The IMMPA Framework, ed. R. Agénor, A. Izquierdo, and H.T. Jensen. Chapter 7. Oxford: Blackwell Publishing.

Ercan, H., and A. Tansel. 2006. How to approach the challenge of reconciling labor flexibility with job security and social cohesion in Turkey. Paper prepared by the Turkish Expert Group's for the European Council's FORUM 2005 (Strasbourg).

Gibson, B. 2005. The transition to a globalized economy: Poverty, human capital and the informal sector in a structuralist CGE model. Journal of Development Economics, 78: 60-94.

Independent Social Scientists' Alliance (ISSA). 2006. Turkey and the IMF: Macroeconomic policy, patterns of growth and persistent fragilities. Penang, Malaysia: Third World Development Network.

Tunal, I. 2003. Background study on the labour market and employment in Turkey. Paper prepared for the European Training Foundation, Torino, Italy.

Voyvoda, E., and E. Yeldan. 2005. IMF programs, fiscal policy and growth: Investigation of macroeconomic alternatives in an OLG model of growth for Turkey. Comparative Economic Studies 47: 41-79. 